\title{
Water Resistance of Basic Magnesium Sulfate Cement
}

\author{
WU Chengyou $^{1, \text { a }}$, ZHANG Huifang ${ }^{2, \text { b }}$, ZHANG Wuyu ${ }^{1, c}$, LI Hui ${ }^{1, \mathrm{~d}}$, XING Sainan ${ }^{1, \mathrm{~d}}$ and \\ CHEN Wenhai ${ }^{1, \mathrm{e}}$, \\ ${ }^{1}$ School of Civil Engineering, Qinghai University, Xining, China; \\ ${ }^{2}$ Qinghai Institute of Salt Lake, Chinese Academy of Sciences, Xining, China; \\ awuchengyou86@163.com, brhf233007@126.com, ${ }^{\mathrm{c}} 709196208 @$ qq.com, ${ }^{\mathrm{d}} 365329508 @$ @q.com \\ d380541750@qq.com, ${ }^{\mathrm{e}} 810159416 @ q q . c o m$
}

\begin{abstract}
Water resistance of basic magnesium sulfate (BMS) cement has been studied in this paper. The solubility of main hydration of $5 \mathrm{Mg}(\mathrm{OH})_{2} \cdot \mathrm{MgSO}_{4} \cdot 7 \mathrm{H}_{2} \mathrm{O}$ in BMS cement has been analyzed by analyzing ions changes in $5 \mathrm{Mg}(\mathrm{OH})_{2} \cdot \mathrm{MgSO}_{4} \cdot 7 \mathrm{H}_{2} \mathrm{O}$ solution. Compressive strength and softening coefficient changes of BMS cement after immersing in water have been tested to evaluate water resistance of BMS cement. And crystal compositions and microstructure of BMS cement before and after immersing in water has been analyzed by XRD and SEM to study the mechanism. These results show that $5 \mathrm{Mg}(\mathrm{OH})_{2} \cdot \mathrm{MgSO}_{4} \cdot 7 \mathrm{H}_{2} \mathrm{O}$ possesses a low solubility at room temperature. Basic magnesium sulfate cement displayed an excellent water resistance based on additives in basic magnesium sulfate cement can inhibit the hydration of hard burnt $\mathrm{MgO}$ to sheet-like $\mathrm{Mg}(\mathrm{OH})_{2}$ and reduce crystallization stress in BMS cement.
\end{abstract}

\section{Introduction}

As a kind of new air-dried magnesia-based cementing material, basic magnesium sulfate (BMS) cement was developed after magnesium oxychloride (MOC) cement and magnesium oxysulfate (MOS) cement [1,2]. Although BMS cement also belongs to the ternary cementitious system of $\mathrm{MgO}-\mathrm{MgSO}_{4}-\mathrm{H}_{2} \mathrm{O}$ as similar to MOS cement, it is a kind of modified MOS cement with more excellent performance material $[3,4]$. Researchers commonly believe that ternary cementitious system of $\mathrm{MgO}-\mathrm{MgSO}_{4}-\mathrm{H}_{2} \mathrm{O}$ compared with $\mathrm{MOC}$ cement has some advantages such as better high temperature resistance, better steel-protection, not easy to absorb moisture and good water resistance. However, these views are just speculation.

Compared with MOC cement, reports about application of ternary cementitious system of $\mathrm{MgO}-\mathrm{MgSO}_{4}-\mathrm{H}_{2} \mathrm{O}$ are less. And the potential and important reason is that it is difficult to improve the mechanism strength. Compressive strength of cement mainly rests with the

\footnotetext{
*Corresponding author:wuchengyou86@163.com
} 
category and the content of basic magnesium sulfate containing in ternary cementitious system of $\mathrm{MgO}-\mathrm{MgSO}_{4}-\mathrm{H}_{2} \mathrm{O}$ [5]. According to Cole's report, four magnesium subsulfate in ternary systems $\left(\mathrm{MgO}-\mathrm{MgSO}_{4}-\mathrm{H}_{2} \mathrm{O}\right)$ are $5 \mathrm{Mg}(\mathrm{OH})_{2} \cdot \mathrm{MgSO}_{4} \cdot 3 \mathrm{H}_{2} \mathrm{O} \quad(5 \cdot 1 \cdot 3$ phase), $3 \mathrm{Mg}(\mathrm{OH})_{2} \cdot \mathrm{MgSO} 4 \cdot 8 \mathrm{H}_{2} \mathrm{O}(3 \cdot 1 \cdot 8$ phase $), \quad \mathrm{Mg}(\mathrm{OH})_{2} \cdot 2 \mathrm{MgSO}_{4} \cdot 3 \mathrm{H}_{2} \mathrm{O}(1 \cdot 2 \cdot 3$ phase $)$, and $\mathrm{Mg}(\mathrm{OH})_{2} \cdot \mathrm{MgSO}_{4} \cdot 5 \mathrm{H}_{2} \mathrm{O}(1 \cdot 1 \cdot 5$ phase $)$ between $30^{\circ} \mathrm{C} \sim 120^{\circ} \mathrm{C}$. At 1980 , Urwongse and his colleague studied phase relations in MOS cement prepared by $\mathrm{MgO}$ and sulphuric acid $\left(\mathrm{H}_{2} \mathrm{SO}_{4}\right)$ solution and they found that only $\mathrm{Mg}(\mathrm{OH})_{2}$, unreached $\mathrm{MgSO}_{4} \cdot \mathrm{nH}_{2} \mathrm{O}(\mathrm{n}=1,6$ or 7$)$ and $3 \cdot 1 \cdot 8$ phase is stable at temperature of $23 \pm 3^{\circ} \mathrm{C}$. In their reports, they also indicated that the reasons of lower compressive strength of MOS cement is that it is difficult to prepare MOS cement with more than $50 \%$ of $3 \cdot 1 \cdot 8$ phase at normal temperature. In Deng's [5] report, compressive strength of MOS cement can be improved obviously by adding a specific additives due to forming new basic magnesium sulfate in MOS cement. In our previous research[6], A large amount of needle-like new hydration phase generates in ternary cementitious system of $\mathrm{MgO}-\mathrm{MgSO}_{4}-\mathrm{H}_{2} \mathrm{O}$ by adding proper additives such as citric acid, which improves its strength by two to three times. This new hydration phase was determined to $5 \mathrm{Mg}(\mathrm{OH})_{2} \cdot \mathrm{MgSO}_{4} \cdot 7 \mathrm{H}_{2} \mathrm{O}(5 \cdot 1 \cdot 7$ phase $)$ by chemical analysis, $\mathrm{TG}$ analysis and $\mathrm{X}$-ray diffraction in our later reports[8]. $5 \cdot 1 \cdot 7$ phase is layer structure constituted of $\mathrm{Mg}-\mathrm{O}$ octahedron as framework and $\mathrm{SO}_{4}{ }^{2-}, \mathrm{H}_{2} \mathrm{O}$, and $\mathrm{OH}^{-}$as filling ion (molecule) in the interlayer. In view of the main hydration phase changing, we define this kind of modified MOS cement with large amount of $5 \cdot 1 \cdot 7$ phase as BMS cement.

To make BMS cement widely used in civil engineering, it should have good water resistances besides high strength especially BMS cement is used in outdoor environment. At present, reports about water resistance of magnesia-based cement material are only focus on that of MOC cement. As is known [7, 8], the main strength hydration phase of $5 \mathrm{Mg}(\mathrm{OH})_{2} \cdot \mathrm{MgCl}_{2} \cdot 8 \mathrm{H}_{2} \mathrm{O}$ easily dissolve in water, which is main factor of poor water resistance of MOC cement. There are a variety of literatures, citations, and patents published $[9,10]$ about methods to improve water resistance of MOC cement. For instance, by adding phosphoric acid, coal fly ash and other additives or miner admixture into MOC can evidently improve water resistance because it can change the crystal habit [11,12] of $5 \mathrm{Mg}\left(\mathrm{OH}_{22} \cdot \mathrm{MgCl}_{2} \cdot 8 \mathrm{H}_{2} \mathrm{O}\right.$ and block pore in $\mathrm{MOC}$ cement to slow the dissolve rate . However, almost no reports about water resistance of ternary cementitious system of $\mathrm{MgO}-\mathrm{MgSO}_{4}-\mathrm{H}_{2} \mathrm{O}$, which limit BMS cement widely used. In this paper, we will investigate the water resistance of BMS cement and study the mechanism. Firstly, the dissolve property of $5 \cdot 1.7$ phase will be investigate. And then the differences of water resistance mechanism of BMS cement and MOS cement.

\section{Experimental}

\subsection{Materials}

$\mathrm{MgO}$ used to prepare pure $5 \cdot 1 \cdot 7$ phase in this study to was analytically pure light weight magnesia with $99.0 \%$ active $\mathrm{MgO}(\mathrm{a}-\mathrm{MgO})$ from Shanghai Hongde Ltd., China.

$\mathrm{MgO}$ used to prepare BMS cement samples was light-burnt magnesia (LBM) powder with an average particle size of about $20 \mu \mathrm{m}$ and provided from Liaoning, China. Typical chemical analysis is listed in Table1. Because only active $\mathrm{MgO}(\mathrm{a}-\mathrm{MgO})$ can hydrate and convert to magnesium subsulfate in magnesium sulfate solution within the setting process of MOS cement [13], it is necessary to know the content of a-MgO in the LBM so that the material mixture ratio and its effects on the properties of MOS cement can be compared 
between cements made using different LBM sources. The content of a-MgO used in this work was determined to be $58.50 \%$ by the standardized hydration method mentioned [14].

Magnesium sulfate (MgSO4.7H2O) was analytically pure and purchased from Tianjin Hongyan Ltd., China. Organic acids such as citric acid are proper additives for BMS cement to promote $5 \cdot 1 \cdot 7$ phase generates and growth and Inhibit that of $\operatorname{Mg}(\mathrm{OH}) 2$, which can improve compressive strength of BMS cement. In view of this point, analytically pure citric acid $(\mathrm{C} 6 \mathrm{H} 8 \mathrm{O} 7 \cdot \mathrm{H} 2 \mathrm{O})$ was used as additives in BMS cement in this study.

Table 1 Chemical Composition Of Light Burnt Magnesia Powder

\begin{tabular}{|c|c|c|c|c|c|c|}
\hline Chemical composition & $\mathrm{MgO}$ & $\mathrm{CaO}$ & $\mathrm{SiO} 2$ & $\mathrm{Fe} 2 \mathrm{O} 3$ & $\mathrm{Al} 2 \mathrm{O} 3$ & I.L \\
\hline Mass fraction/\% & 80.20 & 1.30 & 6.07 & 0.41 & 0.15 & 11.87 \\
\hline
\end{tabular}

\subsection{Preparation of specimens}

For the synthesis of the $5 \cdot 1 \cdot 7$ phase, $100.0 \mathrm{~g}$ pure light weight magnesia $\mathrm{MgO}$ was mixed with $237.6 \mathrm{~g}$ magnesium sulfate solution with $0.5 \mathrm{~g}$ citric acid and mass fraction of $25 \%$ (The molar ratio of a-MgO/MgSO 4 is 5). The mixing time of the paste was $2 \mathrm{~min}$. The paste was poured into a plastic, sealed bag stored at $20^{\circ} \mathrm{C} \pm 1{ }^{\circ} \mathrm{C}$ for $168 \mathrm{~h}$ to make all the a-MgO react to form $5 \cdot 1 \cdot 7$ phase.

To prepare BMS cement specimens for testing water resistance. The molar ratios of a-MgO : MgSO 4 were selected 3 7 (3, 5, 7), and the molar ratio of $\mathrm{H}_{2} \mathrm{O}: \mathrm{MgSO}_{4}$ were selected from 16 20 $(16,18,20$ and 24). The dosage of citric acid in BMS cement was $0.5 \%$ by weight of LBM. First, a quantitative and concentrated magnesium sulfate solution was prepared. Pre-weighted LBM and magnesium sulfate solution were blended and then stirred well to form BMS cement or MOS cement pastes. Pastes were cast into $40 \times 40 \times 40 \mathrm{~mm}^{3}$ polyethylene molds and cured at temperature of $20 \pm 3^{\circ} \mathrm{C}$ and relative humidity of $35 \pm 5 \%$ for 24 hours before demolding.

\subsection{Analytical procedure}

To study the dissolving properties of $5 \cdot 1 \cdot 7$ phase, $1.0 \mathrm{~g} 5 \cdot 1 \cdot 7$ phase powder with mean grain size less than $75 \mu \mathrm{m}$ was soaked in $100.0 \mathrm{ml}$ sealed deionizer water at magnetic stirring rate of $150 \mathrm{r} / \mathrm{min}$ (in a constant temperature bath with temperature of $25 \pm 0.1^{\circ} \mathrm{C}$ ). At stated times to analysis ions concentration and $\mathrm{pH}$ changes in liquid phase and crystal phase changes of the solid phase.

The compressive strength of BMS cement cured for 28 days at room temperature and relative humidity of $35 \pm 5 \%$ was tested on a testing machine with maximum force of 300 $\mathrm{kN}$ according to cement strength test method standard ASTM-C109.Triplicate samples were tested. The crushed cement was reduced to a powder D90 $<30 \mu \mathrm{m}$ for crystal phase composition analyzed on an X-ray diffractometer with $\mathrm{Cu}$ target. And XRD spectrums were fitting with Topas4.2 software to determine relative amount of crystal phases in BMS cement. The microstructures of cement samples were characterized by scanning electron microscopy (SEM, JSM-5610LV) on fractured surfaces after gold coating.

To evaluate the water resistance of MOS or BMS cement specimens, specimens cured for 28 days in air were dipped in water at $20 \pm 3^{\circ} \mathrm{C}$. The liquid-solid mass ratio keeps at 20:1, and water was changed once every 7 days. The compressive strength of the samples after different immersion time in water was measured and used to calculate the softening coefficient (Rf) as follows: 


$$
\mathrm{R}_{f}=\frac{\mathrm{R}(\mathrm{w}, \mathrm{n})}{\mathrm{R}(\mathrm{A}, 28)}
$$

Here $\mathrm{R}(\mathrm{w}, \mathrm{n})$ and $\mathrm{R}(\mathrm{A}, 28)$ denote the compressive strength of specimens after immersion in water for $\mathrm{n}$ days and the compressive strength of specimens cured in air for 28 days, respectively.

\section{Results and Discussion}

\subsection{The dissolving properties of 5.1.7 phase}

Table 2 shows $\mathrm{Mg}^{2+}$ and $\mathrm{SO}_{4}{ }^{2-}$ concentration and $\mathrm{pH}$ changes in liquid phase. After 7 days, the liquid and solid phases reach equilibrium state. It can be inferred that about $0.00281 \mathrm{~mol}$ $5 \cdot 1 \cdot 7$ phase dissolves in $1.0 \mathrm{~L}$ water considering $1 \mathrm{~mol} 5 \cdot 1 \cdot 7$ phase contains only $1 \mathrm{~mol} \mathrm{SO}_{4}{ }^{2-}$. Therefore, about $0.15 \mathrm{~g} 5 \cdot 1 \cdot 7$ phase has been dissolved in $100.0 \mathrm{ml}$ deionizer water. It can be easily seen that the molar ratio of $\mathrm{Mg}^{2+} / \mathrm{SO}_{4}{ }^{2-}$ is about 1 and the concentration of $\mathrm{OH}^{-}$is far less than that of $\mathrm{Mg}^{2+}$ and $\mathrm{SO}_{4}{ }^{2-}$ in liquid phase. So, the dissolving of 5.1.7 is in the form of $\mathrm{MgSO}_{4}$ dissolving in water, and it can be expressed as follow:

$$
5 \mathrm{Mg}(\mathrm{OH})_{2} \cdot \mathrm{MgSO}_{4} \cdot 7 \mathrm{H}_{2} \mathrm{O}(\mathrm{s}) \rightarrow 5 \mathrm{Mg}(\mathrm{OH})_{2}(\mathrm{~s})+\mathrm{Mg}^{2+}(\mathrm{aq})+\mathrm{SO}_{4}{ }^{2-}(\mathrm{aq})+7 \mathrm{H}_{2} \mathrm{O}
$$

As a result, the approximate solubility of $5 \cdot 1 \cdot 7$ phase is equal to the sum of $\mathrm{Mg}^{2+}$ and $\mathrm{SO}_{4}{ }^{2-}$ mass in $100.0 \mathrm{~g}$ deionizer water. After calculation, approximate solubility of $5 \cdot 1 \cdot 7$ phase was about $0.034 \mathrm{~g} / 100 \mathrm{~g}$. Table 3 summarizes solubility data of main hydration production of common cementing materials. As can be seen the solubility of $5 \cdot 1 \cdot 7$ phase is only about $1 / 6,1 / 1708$ and $1 / 2359$ that of gypsum, $3 \cdot 1 \cdot 8$ phase and $5 \cdot 1 \cdot 8$ phase respectively. And, the solubility of $5 \cdot 1 \cdot 7$ phase is approximate $\mathrm{CSH}$ in typical hydraulic cementing materials of Portland cement and both of them are at a low order of magnitude.

Table2 Mg2+ And So42- Concentration And Ph Changes In Liquid Phase At Different Time

\begin{tabular}{|c|c|c|c|}
\hline Time/days & $\mathrm{C}_{\mathrm{Mg} 2+}$ & $\mathrm{C}_{\mathrm{SO4}}$ & $\mathrm{pH}$ \\
\hline 0.5 & 0.00189 & 0.00185 & 8.5 \\
\hline 1 & 0.00270 & 0.00264 & 8.7 \\
\hline 2 & 0.00275 & 0.00274 & 8.9 \\
\hline 3 & 0.00290 & 0.00277 & 8.8 \\
\hline 7 & 0.00291 & 0.00281 & 9.0 \\
\hline 14 & 0.00290 & 0.00280 & 9.0 \\
\hline
\end{tabular}

Table 3 Solubility Data Of Main Hydration Production Of Common Cementing Materials

\begin{tabular}{|c|c|c|c|c|}
\hline \multirow{2}{*}{ cementing materials systerm } & $\begin{array}{c}\text { Name of cementing } \\
\text { materials }\end{array}$ & $\begin{array}{c}\text { The main } \\
\text { hydration } \\
\text { production }\end{array}$ & $\begin{array}{c}\text { solubility } \\
(\mathrm{g} / 100 \mathrm{~g})\end{array}$ & $\begin{array}{c}\text { Temperatur } \\
\text { e }\left({ }^{\circ} \mathrm{C}\right)\end{array}$ \\
\hline \multirow{2}{*}{$\begin{array}{c}\text { Calcium-base cementing } \\
\text { materials }\end{array}$} & Gypsum & $\mathrm{CaSO}_{4} \cdot 2 \mathrm{H}_{2} \mathrm{O}$ & 0.205 & 20 \\
\cline { 2 - 5 } Magnesia-base cement & Portland cement & $\mathrm{CSH}(\mathrm{C} / \mathrm{S}=1.0)$ & 0.012 & 25 \\
\cline { 2 - 5 } & MOC & $5 \cdot 1 \cdot 8$ phase & 80.2 & 20 \\
\cline { 2 - 5 } & BMS & $5 \cdot 1 \cdot 8$ phase & 58.08 & 25 \\
\hline
\end{tabular}


Table 4 Quantitative Analysis Results Of Solid Phase After 5·1 7 Phase Specimen Dissolving

\begin{tabular}{|c|c|c|c|c|}
\hline Dissolving time & $\begin{array}{c}5 \cdot 1 \cdot 7 \text { crystal } \\
\text { phase } / \%\end{array}$ & $\mathrm{Mg}(\mathrm{OH})_{2} / \%$ & $\begin{array}{c}\text { crystallite } \\
\text { dimension } / \mathrm{nm}\end{array}$ & $\mathrm{Rwp} / \%$ \\
\hline 0 & 100 & 0 & 42.0 & 6.814 \\
\hline $1 \mathrm{~d}$ & 99.98 & 0.02 & 44.6 & 7.249 \\
\hline $7 \mathrm{~d}$ & 99.97 & 0.03 & 45.0 & 6.988 \\
\hline $28 \mathrm{~d}$ & 99.98 & 0.02 & 42.5 & 6.024 \\
\hline
\end{tabular}

\subsection{Water resistance of MOS cement}

Table 4 shows the compressive strength changes of MOS cement with different materials molar ratios after immersing in water for different time. It can be seen, water resistance of MOS is very poor likes MOC cement without any additives. With the increasing of the molar ratios of a-MgO/MgSO , water resistance of MOS cement becomes worse and even cracking and breakdown after immersing in water for short time. For instance, when the molar ratios of a-MgO/ $\mathrm{MgSO}_{4}$ is 5 , the compressive strength decreases to be $7.5 \mathrm{MPa}$ from $37.5 \mathrm{MPa}$ by about $80 \%$ after immersing for 14 days. When the molar ratio of a-MgO/MgSO 4 increases to 7 , the loss ratio of compressive strength can be up to about $85 \%$ and samples becomes cracking, breakdown finally.

Fig. 2 shows XRD patterns of MOS cement before and after immersing in water for 28 days. MOS cement before immersing in water mainly consist of $5 \cdot 1 \cdot 7$ phase, $\operatorname{Mg}(\mathrm{OH})_{2}$, $\mathrm{MgO}, \mathrm{MgCO}_{3}$. This part of $\mathrm{MgO}$ is mainly hard burnt magnesia coming from materials, and its hydration ratio is very slowly in air. After immersing in water for 28 days, bits of $5 \cdot 1 \cdot 7$ phase still can be seen in MOS cement. From quantitative analysis results (Table 5), the content of $\mathrm{MgO}$ decreases evidently from $15.05 \%$ to $0.54 \%$ and that of $\mathrm{Mg}(\mathrm{OH})_{2}$ obviously increases from $45.44 \%$ to $62.10 \%$. Therefore one of reasons is that the low water resistance of the MOS cement is that most of the unreacted $\mathrm{MgO}$ (hard burnt magnesia) in the control samples hydrating to $\mathrm{Mg}(\mathrm{OH})_{2}$ upon immersion in water. This reaction causes the cement structure to become looser, and even crack, asdifferent densities of $\mathrm{MgO}(\mathrm{q}=3.5 \mathrm{~g} / \mathrm{cm} 3)$ and $\mathrm{Mg}(\mathrm{OH})_{2}(\mathrm{q}=2.4 \mathrm{~g} / \mathrm{cm} 3)$. It is worth noted that the decrement of content of $5 \cdot 1 \cdot 7$ phase is not sharply.

it is well known ${ }^{[9,11]}$ that MOC cement without any additives has poor water resistance, because the $5 \cdot 1 \cdot 8$ and $3 \cdot 1 \cdot 8$ phases in MOC are soluble in water. However, dissolving pf strength phase of $5 \cdot 1 \cdot 7$ phase is not the main reason of poor water resistance of MOS cement, which is different from that of MOC cement without any additives.

Fig. 1 shows SEM images of MOS cement before and after immersing in water for 28 days. The compaction rate of MOS specimen before immersing in water is high than that of specimen after immersing in water, which is maybe another reason of poor water resistance of MOS cement. An amount of pore appears in MOS cement after immersing water. Two causes can be inferred. One is that burnt magnesia hydration into thin sheets of $\mathrm{Mg}(\mathrm{OH})_{2}$, which leads to the gap of matrix loose and leave; The other is that unreacted $\mathrm{Mg}^{2+}$ and $\mathrm{SO}_{4}{ }^{2-}$ dissolving in water because magnesium sulfate is difficult react with a- $\mathrm{MgO}$ completely . 
Table 5 Compressive Strength Of Mos Cement After Immersing In Water For Different Time (Mpa)

\begin{tabular}{|c|c|c|c|c|c|}
\hline a-MgO: $\mathrm{MgSO}_{4}: \mathrm{H}_{2} \mathrm{O}$ & Before immersing & $\begin{array}{l}1 \\
\text { day }\end{array}$ & 3 days & 14 days & 28 days \\
\hline $3: 1: 16$ & 30.2 & 15.4 & 10.6 & 7.4 & cracking \\
\hline $5: 1: 18$ & 37.5 & 15.0 & 13.9 & 7.5 & cracking \\
\hline $7: 1: 20$ & 32.4 & 5.0 & $\begin{array}{l}\text { crackin } \\
\mathrm{g}\end{array}$ & severe cracking & $\begin{array}{l}\text { breakdow } \\
\mathrm{n}\end{array}$ \\
\hline
\end{tabular}

Table 6 Quantitative Analysis Results Of Phases Content In Mos Cement By Topas 4.2 (\%)

\begin{tabular}{|c|c|c|c|c|c|c|c|}
\hline \multicolumn{4}{|c|}{ Before immersing in water } & \multicolumn{4}{|c|}{ After immersing in water for 28 days } \\
\hline $5 \cdot 1 \cdot 7$ phase & $\mathrm{Mg}(\mathrm{OH})_{2}$ & $\mathrm{MgCO}_{3}$ & $\mathrm{MgO}$ & $5 \cdot 1 \cdot 7$ phase & $\mathrm{Mg}(\mathrm{OH})_{2}$ & $\mathrm{MgCO}_{3}$ & $\mathrm{MgO}$ \\
\hline 31.99 & 45.44 & 6.39 & 15.05 & 30.21 & 62.10 & 5.22 & 0.54 \\
\hline
\end{tabular}

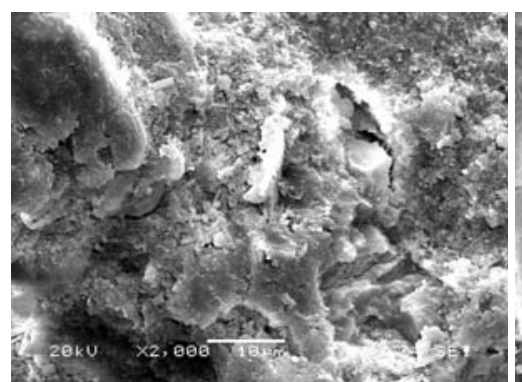

(a)

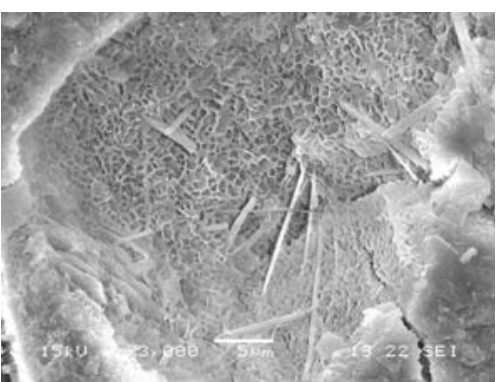

(b)

Fig.1 SEM images of MOS cement before (a) and after immersing in water for 28 days (b)

\subsection{Water resistance of BMS cement}

Table 6 shows the compressive strength and $\mathrm{R}_{\mathrm{f}}$ of BMS cement after immersing in water for different time. Before immersing in water BMS cement has higher strength. For example, when a-MgO: $\mathrm{MgSO}_{4}: \mathrm{H}_{2} \mathrm{O}$ is 7:1:20, the compressive strength is $80.9 \mathrm{Mpa}$ which is about 2.5 times of MOS cement. The reason is that more $5 \cdot 1 \cdot 7$ phase can formed in cement .

The $R_{f}$ is keep above 0.87 and 0.83 after immersing in water for 28 days and 180 days respectively. For instances, The compressive can still maintain 58.1 MPa after immersing 180 days. It can be seen BMS cement posses better water resistances than MOS cement even at high molar ratio of a-MgO: $\mathrm{MgSO}_{4}$. In view of high strength before and after immersing in water, the range of application of BMS cement should be more widely.

Fig. 3 shows XRD patterns of BMS cement before and after immersing in water for 180 days. After immersing in water for 180 days, diffraction peaks of 5.1 .7 phase is still obviously seen. As similar with MOS cement, diffraction peaks of $\mathrm{MgO}$ has been reduced and that of $\mathrm{Mg}(\mathrm{OH})_{2}$ enhanced. From Table 7, the content of $5 \cdot 1 \cdot 7$ phase and $\mathrm{Mg}(\mathrm{OH})_{2}$ can still keep at more than $50 \%$ and less than $40 \%$ respectively. Although, a certain amount of $\mathrm{Mg}(\mathrm{OH})_{2}$ generates by hard burnt $\mathrm{MgO}$ hydration in water, there are no sheet-like $\mathrm{Mg}(\mathrm{OH})_{2}$ crystal can be seen in SEM image (Fig.1) of BMS cement after immersing in water for 180 days. Above all, it can inferred two reasons for good water resistance of BMS cement. One is that BMS cement posses high tensile strength to overcome the crystallization stress produce 
by hard burnt $\mathrm{MgO}$ hydration. The other is that additives such as citric acid can inhabit the crystal growth of $\mathrm{Mg}(\mathrm{OH})_{2}$ which reduces crystallization stress in BMS cement after immersing in water.

Table 7 The Compressive Strength (Mpa) And Rf Of Bms Cement After Immersing In Water

\begin{tabular}{|l|c|c|c|c|}
\hline a-MgO: $\mathrm{MgSO}_{4}: \mathrm{H}_{2} \mathrm{O}$ & Before immersing & 28 days & 90 days & 180 days \\
\hline $3: 1: 16$ & 58.9 & $54.6(0.92)$ & $51.0(0.87)$ & $50.8(0.86)$ \\
\hline $5: 1: 18$ & 70.3 & $61.6(0.88)$ & $62.3(0.89)$ & $58.1(0.83)$ \\
\hline $7: 1: 20$ & 80.9 & $70.1(0.87)$ & $72.3(0.89)$ & $68.7(0.85)$ \\
\hline $9: 1: 24$ & 65.9 & $58.1(0.88)$ & $57.4(0.87)$ & $55.1(0.84)$ \\
\hline
\end{tabular}

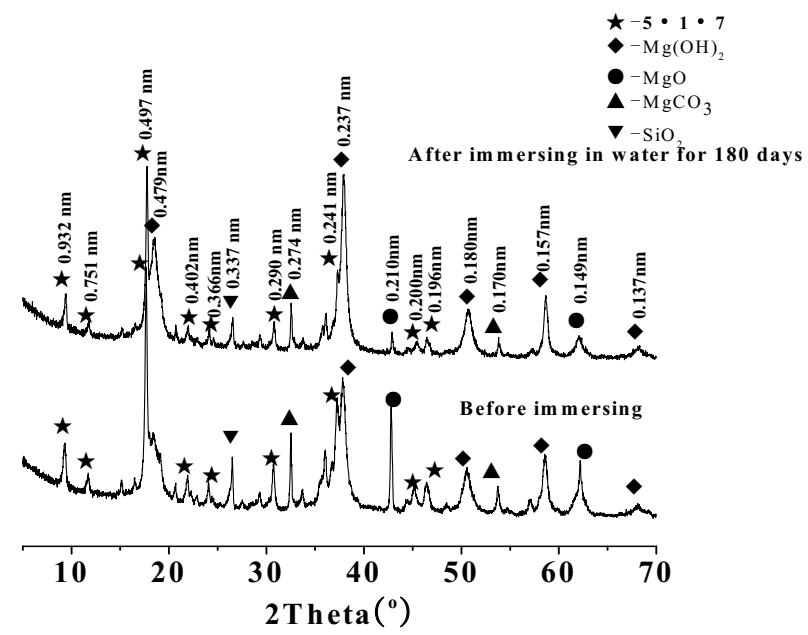

Fig.2 XRD patterns of BMS cement before and after immersing in water for 180 days

Table 8 quantitative Analysis Results Of Phases Content In Bms Cement (A-Mgo: Mgso4: H2o=7:1:20)

Before And Immersing In Water For 180 Days By Topas 4.2 (\%)

\begin{tabular}{|c|c|c|c|c|c|c|c|c|}
\hline \multicolumn{3}{|c|}{ Before immersing in water } & & \multicolumn{3}{c|}{ After immersing in water for 180 days } \\
\hline $\begin{array}{c}5 \cdot 1 \cdot 7 \text { Phas } \\
\mathrm{e}\end{array}$ & $\mathrm{Mg}(\mathrm{OH})_{2}$ & $\mathrm{MgCO}_{3}$ & $\begin{array}{c}\mathrm{Mg} \\
\mathrm{O}\end{array}$ & & $5 \cdot 1 \cdot 7 \mathrm{phase}$ & $\mathrm{Mg}(\mathrm{OH})_{2}$ & $\mathrm{MgCO}_{3}$ & $\mathrm{MgO}$ \\
\hline 60.24 & 24.13 & 5.43 & 8.83 & & 50.65 & 37.24 & 8.54 & 1.38 \\
\hline
\end{tabular}




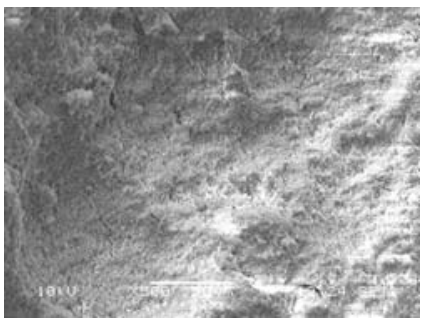

(a)

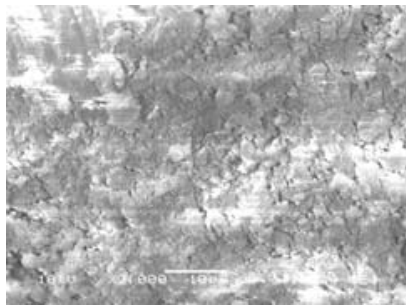

(b)

Fig.3 SEM images of BMS cement before (a) and after immersing in water for 180 days(b)

\section{Conclusions}

Water resistance of BMS cement has been studied. We have concluded that:

(1) The main strength hydration phase $5 \mathrm{Mg}(\mathrm{OH})_{2} \cdot \mathrm{MgSO}_{4} \cdot 7 \mathrm{H}_{2} \mathrm{O}$ in basic magnesium sulfate cement has a low solubility of $0.034 \mathrm{~g} / 100 \mathrm{~g}$.

(2) Magnesium oxysulfate cement had crazed completely after 28day immersing in water, and the reason was that excess hard burnt $\mathrm{MgO}$ in magnesium oxysulfate cement hydrated and led to crystallization stress which destroyed the cement structure.

(3) Basic magnesium sulfate cement displayed an excellent water resistance. The main reason for this phenomenon is that additives in basic magnesium sulfate cement can inhibit the hydration of $\mathrm{MgO}$ to weaken the crystallization stress and low solubility $5 \cdot 1 \cdot 7$ phase .

\section{Acknowledgments}

Partial financial support from by the National Natural Science Foundations of China (Grant No. U1407104 and 214011209) and Natural Science Foundations of Qinghai (2015-ZJ-937Q and 2015-ZJ-947Q). This project was also supported by Young and Middle-aged Scientific Research Funds of Qinghai University (2014-QGY-1) and Foundation for Teaching and Scientific Research Innovation Team of Education Department of Qinghai.

\section{References}

1. C.Y. Wu, H.F. Yu, H.F. Zhang, The effects of aluminum-leached coal fly ash residue on magnesium oxycloride cement, Adv. Cem. Res. 25 ( 2013) 254-261.

2. Z.J. Li, C.K. Chau, Influence of molar ratios on properties of magnesium oxychloride cement, Cem. Concr. Res. 37(2007) 866- 870.

3. C.Y. Wu, H.F. Yu, J .M. Dong, Effects of material ratio, fly ash and citric acid on magnesium oxysulfate cement, ACI Mater. J., 111(2014) 291-297.

4. E.D. Robert, P. Melanie, F.Danielaf, $3 \mathrm{Mg}(\mathrm{OH})_{2} \cdot \mathrm{MgSO}_{4} \cdot 8 \mathrm{H}_{2} \mathrm{O}$ : A Metastable Phase in the System $\mathrm{Mg}(\mathrm{OH})_{2}-\mathrm{MgSO}_{4}-\mathrm{H}_{2} \mathrm{O}, \mathrm{Z}$. Anorg. Allg. Chem. 639(2013) 1827-1833.

5. D.H. Deng, A study on the theories and techniques for improving the properities of $\mathrm{MgO}$-based basic salt cements and their articles, Central South University, Chang Sha, 2005 , pp.151-161.

6. R. Tomce, C.Y. Wu, H.F. Yu, B.O. Yang, E.D. Robert, Structural characterization of new magnesium oxysulfate hydrate cement phase and its surface reactions with atmospheric carbon dioxide, J. Amer. Ceram. Soc. 96 (2013) 3609-3616. 
7. C.A. Sorrell, C.R. Armstrong. Reactions and Equilibria in magnesium oxychloride cements, J. Amer. Ceram. Soc., 59(1976) 51-54.

8. H. J. Ba, H.Guan, Influence of $\mathrm{MgO} / \mathrm{MgCl} 2$ molar ratio on phase stability of magnesium oxychloride cement. Journal of Wuhan University of Technology-Materials Science Edition 24 (2009) 476-481.

9. D.H. Deng, The mechanism for soluble phosphates to improve the water resistance of magnesium oxyehloride cement, Cem. Concr. Res. 33 (2003) 1311- 1317.

10. K.J. Xu, J.T. Xi, Y.Q. Guo, S.V.H. Dong. Effects of a new modifier on the water resistance of magnesite cement tiles, Solid State Sci., 2012, 14(1): 10-14.

11. Z.J. Li, C.K. Chau, Influence of Molar Ratios on Properties of Magnesium Oxychloride Cement, Cem. Concr. Res. 37(2007) 866-870.

12. H.Q. Li, G. Z Li, Y .Z. Yu, The Influence of Compound Additive on Magnesium Oxychloride Cement/Urban Refuse Floor Tile, Constr. Build. Mater. 22(2008 ) 521-525.

13. Z.J. Li, C.K. Chau, Reactivity and function of magnesium oxide in Sorel cement, J. Mater. Civil Eng. 20(2008 239-244.

14. C.K. Chau, Z.J. Li, Accelerated Reactivity Assessment of Light Burnt Magnesium Oxide, J. Am. Ceram. Soc. 91(2008) 1640-1645 